\title{
Pre- and postharvest technologies to extend the shelf life of Prunus cerasus
}

\author{
${ }^{1}$ Kata Mihály $-{ }^{2}$ Csilla Kovács $-{ }^{2}$ Ferenc Takács $-{ }^{1}$ Erzsébet Sándor \\ ${ }^{1}$ University of Debrecen, Faculty of Agricultural and Food Sciences and Environmental Management, Institute of Food Science \\ ${ }^{2}$ National Agricultural Research and Innovation Center, Fruit Research Institute, Újfehértó \\ mihaly.kata@gmail.com
}

\begin{abstract}
SUMMARY
Fresh tart cherry consumption cannot be increased without the development of an appropriate technology for its elongated storage. This requires the development and optimization of the pre-and postharvest treatments. Currently, we have only limited knowledge about tart cherry (Prunus cerasus L.) postharvest technology, however, related studies on sweet cherry (Prunus avium L.) may be adopted. In this article, we have collected the most important research results in this topic.
\end{abstract}

Keywords: tart cherry, preharvest fungicides, postharvest

\section{INTRODUCTION}

Tart cherry production of the European Union represents a significant volume within the world market. It represents the second largest volume among the produced fruits in Hungary, which is among the most important producers of tart cherries in the EU. The Hungarian export is reported to be between 10 to 20 thousand tons of fresh tart cherries per year, largely to German canning industry. In Hungary, tart cherry is used by food industry, producing canned fruit and juice products, but it is also an important raw material for the alcoholic beverage and confectionary industry. Moreover it has outstanding importance in the food industry as a natural colorant (Inántsy and Balázs, 2004). This fruit has exceptionally beneficial nutritional content, with higher concentration of vitamins, minerals, antioxidants and bioactive components than sweet cherry. However nutritional content considerably decrease during fruit procession (Homoki et al., 2014). There are several tart cherry varieties breeded in Hungary, such as 'Érdi bőtermö'. Other varieties, like 'Debreceni bőtermő' and 'Újfehértói fürtös' varieties are originated from landscape selection. All of them are well suited for fresh consumption due to their harmonious sugar/acid ratio. In spite of the broad scale of the produced tart cherry varieties in Hungary, the fresh tart cherry consumption season restricts only for 4-5 weeks nowadays.

The market and selling prices of interior tart cherry have fluctuated hectically in recent years, often in a given year. The reason for this is partially resulted from the short tart cherry production season which is accompanied by the restricted storage period, as harvested fruit can be stored longer than a few days without remarkable decline. In addition to the prices determined by traders, the prices of the industrial processing tart cherry also have a negative impact on the price of fresh consumption tart cherry (Apáti and Gonda, 2009). Therefore, it is important to develop an appropriate storage for longer period to increase the time for fresh consumption and fruit trade. Fresh fruit usage up to $20-30 \%$ would be desirable. There are several factors, which can influence the shelf-life of the tart cherry, like maturity, seasonal weather conditions, plant protection technology and storage technology. The usage of chemical pesticide is not allowed following the harvest and during the storage in the EU, therefore new pre- and postharvest technology possibilities are studied intensively (Wisniewski and Wilson, 1992). The preharvest applications of different fungicides and biofungicides were studied to conclude their affect for the quality parameters and the decay during storage. Moreover there is a wide range of options available in the postharvest technology such as cooling, modified atmosphere packaging (passive or active), fruit surface cleaning and disinfection of fruit, anti-microbial coating, heat treatment, hydrocooling, radiation or a combination of these. The aim of these processes is to increase the storage and shelf-life time of fruit following the harvest, and keep the nutritional and physiological properties of the fruit as long as possible.

\section{BIBLIOGRAPHY OVERVIEW}

\section{Preharvest technology}

There is an increasing possibility of using different fungicides, biofungicides or biostimulants in the preharvest technology. Feliziani et al. (2013) used synthetic fungicides and their alternatives in pre- and postharvest treatments in Italy. They have evaluated the effectiveness of the different treatments against the fruit pathogen fungi. Cherry fruits were stored at low and room temperature. The trees were treated with chitosan $\left(10 \mathrm{~g} \mathrm{l}^{-1}\right)$, fenhexamide $\left(0.5 \mathrm{~g} \mathrm{l}^{-1}\right)$, nettle extract $\left(10 \mathrm{~g} \mathrm{l}^{-1}\right)$, pine extract $\left(10 \mathrm{~g} \mathrm{l}^{-1}\right)$ and benzothiadiazole (2 $\left.\mathrm{g}^{-1}\right)$ solution three days before the harvest. The fruits were stored at $0.5 \pm 1^{\circ} \mathrm{C}$ for two weeks and then for seven days at $20 \pm 1^{\circ} \mathrm{C}$. Chitosan, nettle and fenhexamide treatments significantly reduced the brown rot (Monilia sp.), grey mould rot (Botrytis sp.) and Rhizopus rot of 'Sweet Heart' cherry. There were no statistically significant differences between the treatments. In the 'Blaze Star' cherries, chitosan, pine extract and fenhexamide reduced the occurrence of Monilia sp. The positive effect of chitosan for the shelf- 
life cherry fruits was also demonstrated in other studies. Applications of $0.1 \%, 0.5 \%$ and $1 \%$ chitosan, seven days before harvest decreased the incidence of the grey mould and the brown rot in two weeks and 7 days long shelf-life tests at $0^{\circ} \mathrm{C}$ (Romanazzi et al., 1999). In another study, methyl salicylate $(1 \mathrm{mM})$ was used in the cherry trees, to study its impact on fruit quality following the harvest and the storage. The storage at $2^{\circ} \mathrm{C}$ at $85 \% \mathrm{RH}$ lasted 28 days. Preharvest methyl salicylate application was concluded to delay the postharvest ripening processes, and resulted in smaller changes in the colour, the fruit firmness and acidity (Giméneza et al., 2015). Erogul (2014) studied the effect of four different calcium containing compounds on '0900 Ziraat' cherry variety. They applied $0.5 \%$ calcium nitrate, $0.5 \%$ calcium chloride, $0.5 \%$ calcium caseinate and $0.2 \mathrm{M}$ calcium hydroxide 30,20 , and 10 days before the harvest. The most effective preharvest calcium treatments were calcium chloride and calcium hydroxide, which $62 \%$ and $66 \%$ reduced cracking. None of the calcium compounds influenced significantly the average fruit weight, and the nutritional content of the fruit. Calcium chloride significantly increased the firmness of the fruit. Preharvest technology is also important for tropical fruits, as longer period last before reaching the consumers. The mango fruit was treated with hexane nano emulsion (EHA). $1.6 \mathrm{mmol}$ solution was used 30 and 15 days before the harvest and the fruits were stored at room $\left(25 \pm 2^{\circ} \mathrm{C}\right)$ and cold $\left(14 \pm 2^{\circ} \mathrm{C}\right)$ temperatures. The data clearly indicated that preharvest sprays of EHA significantly reduced the postharvest diseases such as anthracnose, stem-end rot and other infections, therefore postharvest losses were minimized (Anusuya et al., 2016). Zhu et al. (2016) studied the effectiveness of oxalic acid treatment. It had a positive effect on the quality parameters of kiwi and showed greater resistance to Penicillium expansum during storage in case of preharvest application. Biopesticides also can be used for preharvest treatments. Adaskaveg et al. (2009) demonstrated the efficacy of Luna Privilege, containing fluopyram, which is a broad spectrum fungicide. In other experiments, the effects of various products and biofungicides were studied on postharvest diseases during storage and quality parameters of the fruits were also determined. The effectiveness of microbial antagonists against fungi causing postharvest diseases (such as Penicillium, Botrytis, Monilia) have been proven by many studies over the last decade (Manso and Nunes, 2011; Mari et al., 2012; Bautista-Rosales et al., 2013; Oro et al., 2014).

Biofungicide containing yeast are considered as particularly promising products. Yeasts usually grow more rapidly than the pathogens, moreover they have simple nutritional requirements, are able to colonize the wound site rapidly and they are also effective competitors for space and nutrition (Liu et al., 2013; Parafati et al., 2015; Spadaro and Droby, 2016). Yeasts applied in the biological control have several beneficial biochemical mechanisms:
1. Their selected specific enzymes and antimicrobial agents induce plant resistance.

2. They able to adhere and sticking to different surfaces such as fruits or even to the cells of pathogenic fungi.

3. Forming a biofilm layer on the surface of the wounds prevent it from the pathogens ( $\mathrm{Lu}$ et al., 2013; Lutz et al., 2013).

There are killer type among the antagonist yeasts. Their use is also essential, as they are able to destroy other yeasts, moulds and pathogenic bacteria with their selected extracellular proteins, therefore inhibiting the postharvest decay of fruits (Izgü and Altinbay, 2004; Muccilli et al., 2013). In Pusey and Wilson's (1984) study, Bacillus subtilis was used to control monilia-rot of the stone fruit. Bacterial antagonists, such as Bacillus subtilis and Pseudomonas cepacia, are able to suppress other pathogens on the surface of the fruits and vegetables. These antagonists are producing antibiotics. In Singh and Deverall's experiment (1984), Bacillus subtilis was effectively used to prevent fungal decay of citrus. It was also effective against to Monilinia fructicola in case of tart cherry and peach (Pusey and Wilson, 1984; Utkhede and Sholberg, 1986). Aureobasidium pullulans is a yeast antagonist isolated from peach. It was also successfully used against Monilia species (Monilia laxa, Monilia fructicola and Monilia fructigena). In the experiment, two A. pullulans strains were able to reduce brown rot on peaches and nectarines (Mari et al., 2012). The survival of antagonistic yeasts were examined in another study under field conditions (Shiping et al., 2004). Their biocontrol ability against postharvest diseases was also tested on cherries. Cryptococcus laurentii was the most effective and promising among the three studied antagonists. It good survival and adopted for storage conditions with low temperatures, and modified atmosphere with low $\mathrm{O}_{2}$ and high $\mathrm{CO}_{2}$ concentrations.

\section{Postharvest technology}

Cold storage, packaging, sorting, grading, and processing are all part of the postharvest process, which is the postharvest technology itself. The aims of fruit storage are (i) to extend storage time, (ii) to maintain the original nutritional value, alongside (iii) to reduce weight losses and (iv) to prevent postharvest diseases.

Tart cherry is a non-climacteric fruit. That means, the breathing intensity is constantly decreasing, and fruit already reaches the maturity on the tree, therefore nutritional parameters are the best at the harvest (Takács et al., 2016).

Several studies have proved the effectivity of the modified atmosphere packaging (MAP) for different fruits. Allende et al. (2007) found that MAP reduced the decay of strawberries. Several authors have observed that the optimum relative humidity during storage is between 90 and $95 \%$ for cherry (Hevia et al., 1998; Alique et al., 2005). The tart cherries are among those fruits which tolerates well high $\mathrm{CO}_{2}$ concentration. Cherry, nectarine and peach fruits can also be stored better in $10 \% \mathrm{CO}_{2}$ than in normal 
atmosphere (Patterson, 1982; Retemales et al., 1992; Lurie, 1992). A number of research confirmed that $\mathrm{CO}_{2}$ could increase the shelf-life. When low $\mathrm{O}_{2}$ together with high $\mathrm{CO}_{2}$ concentrations was applied, the fruit quality was maintained for longer time and fungal diseases were suppressed more (Ceponis and Cappellini, 1985; Ke et al., 1991; Prusky et al., 1997).

MAP package was tested for Hungarian cultivars collected from the NARIC Fruitculture Research Institute Újfehértó, in 2015. Only 1-2\% the wane was detected in case of MAP, while the loss was between 6 and $13.1 \%$ following 6 weeks normal atmosphere storage. The decay was almost unnoticeable during the MAP storage, while it was above $20 \%$ in case of normal atmosphere (Takács et al., 2016).

In Zoffoli and Rodriguez's (2014) experiments, the effect of active and passive MAP was studied on 'Sweetheart' cherries. The bags filled with fruit were sealed and the desired gas concentration was reached by the natural breath of the fruits in case of passive MAP. In case of active MAP, the air was removed first from the bag by vacuum, than the desired gas mixture was added. As a control, a non-sealed bag was used and stored for 42 days at $0-1.5^{\circ} \mathrm{C}$, than for 4 days at $5^{\circ} \mathrm{C}$. Following the storage, the colour of stem and cherry, the fruit firmness, the total sugar and acid content, the appearance of fruit injury and decay were studied. Following storage, these parameters were determined again on 4 days stored samples. There was no significant difference between the samples stored in either active or passive MAP. The gas composition of the passive MAP reached the same level, as applied in the active MAP after two days. The decay incidence was lower in case of MAP storage than the control, but this difference disappeared when the samples were stored at $20^{\circ} \mathrm{C}$ for 5 days.

The effects of MAP storage was also studied with the tart cherries 'Érdi jubileum' and 'Érdi bőtermö'. Passive and active MAP $\left(10 \% \mathrm{O}_{2}, 15 \% \mathrm{CO}_{2}, 75 \% \mathrm{~N}_{2}\right)$ were used, during the 42 days storage at $0^{\circ} \mathrm{C}$. MAP storage was found to be more effective than normal atmosphere storage, as smaller change was measured in the examined quality parameters in both varieties. The use of MAP postharvest technology was able to maintaining the sugar / acid ratio and the colour, and reducing the weight loss during storage, and $\mathrm{pH}$ of the fruits has not changed either (Davarynejad et al., 2014).

Gamma irradiation is an effective disinfection method in the food industry. It was used for Hungarian sour cherry cultivars in a test. The harvested fruits were treated with different doses $(0.5 ; 1 ; 2 \mathrm{kGy})$ gamma ionizing radiation and tested for their effect on decay and the colony-forming unit (CFU) of the superficial mould. The ratio of mould populations were also observed. A portion of the treated sour cherries was stored for 6 weeks at a temperature of $0-2^{\circ} \mathrm{C}$ in normal atmosphere and MAP. Ionizing gamma radiation was improved the shelf life of the tested sour cherries. However, the effect of reducing the surface mould's number was not clear. The combination of radiation and the 6-week cold storage in the shelf life test was not successful, as the quality of the sour cherry quickly deteriorated following storage. Modified atmosphere packaging alone, together with ionizing gamma radiation, has been effective in certain cultivar to reduce the surface mould number. Significant differences were found between the varieties (Mihály et al., 2017).

\section{CONCLUSION}

Hungary is recognized as one of the most important producers of the tart cherry in Europe. Hungarian varieties are unique in the world. Hungarian tart cherry production has a remarkable economic potential (Takács et al., 2016). Tart cherry is widely used in the food industry, and some are excellent for fresh consumption. The beneficial effects of fresh tart cherry consumption on health has also been proven. To increase the fresh consumption of tart cherry we need to provide longer availability of fresh fruit. Tart cherries are non-climatic fruits, therefore harvested fruit can be stored for a few days without significant decay. Appropriate storage, preserving nutritional value of the fruits and inhibiting decay should be developed by using pre- and postharvest technologies.

Chitosan was found to be an effective preharvest treatment against decaying fungi in cherry. The application of various calcium compounds, hexane nano-emulsion and oxalic acid were also effective on different fruits, preventing the decay and the change in the quality parameters of the fruit during storage. Using yeast and killer type of yeast instead of fungicide could be successfully as well. Different biofungicides effectively reduced the incidence of monilia-rot and other postharvest diseases. Several authors' research has shown that is better to apply MAP with high (10\%) $\mathrm{CO}_{2}$ content during the storage of tart cherry, than normal atmosphere. The not completely anaerobic conditions with increased $\mathrm{CO}_{2}$ level in combination with cooling can slow the quality of deterioration of the fruit.

There is a few observations on pre- and postharvest technologies in the case of tart cherry, therefore, more research is necessary to develop successful storage technology methods that have been successfully applied to similar fruits. By achieving the most suitable storage technology, it would be possible to increase shelf-life, which would positively influence the increase in the consumption of fresh tart cherry.

\section{ACKNOWLEDGMENTS}

Ferenc Takács was supported by the NAIK GYKI GYU03 project. The publication is supported by the EFOP-3.6.3-VEKOP-16-2017-00008 project. The project is co-financed by the European Union and the European Social Fund. 


\section{REFERENCES}

Adaskaveg, J. A.-Foster, H.-Thompson, D.-Felts D.-Ens, J.-Day K.-Beede, B.-Holtz, B. (2009): Epidemiology and management of pre- and post-harvest diseases of peach, plum, and nectarine. California Tree Fruit Agreement. Annual Research Report. 2950.

Alique, R.-Zamorano, P. J.-Martínez, M. A.-Alonso, J. (2005): Effect of heat and cold treatments on respiratory metabolism and shelf-life of sweet cherry, type picota cv. 'Ambrunés'. Postharvest Biology and Technology. 35:153-165.

Allende, A.-Maŕin, A.-Buendia, B.-Tomas-Barbeŕan, F.-Gil, M. I. (2007): Impact of combined postharvest treatments (UV-C light, gaseous $\mathrm{O} 3$, superatmospheric $\mathrm{O} 2$ and high $\mathrm{CO} 2$ ) on health promoting compounds and shelf-life of strawberries. Postharvest Biology and Technology. 46:201-211.

Anusuya, P.-Nagaraj, R.-Janavi, G. J.-Subramanian, K. S.-Paliyath, G.-Subramanian, J. (2016): Pre-harvest sprays of hexanal formulation for extending retention and shelf-life of mango (Mangifera indica L.) fruits. Scientia Horticulturae 211:231240.

Apáti, F.-Gonda I. (2009): Debreceni álláspont. A meggy ágazat jövője. Debreceni álláspont az agrárium jelenéről, jövőjéről. 223-238. p.

Bautista-Rosales, P. U.-Calderon-Santoya, M.-Servin-Villegas, R.Ochoa-Alvarez, N. A.-Ragazzo-Sanchez, J. A. (2013): Action mechanisms of the yeast Meyerozyma caribbica for the control of the phytopathogen Colletotrichum gloesporioides in mangoes. Biol. Control. 65:293-301.

Ceponis, M. J.-Cappellini, R. A. (1985): Reducing decay in fresh blueberries with controlled atmospheres. HortScience. 20:228229.

Davarynejada-Aryanpooya, Z.-Persely, Sz. (2014): Effect of Modified Atmosphere Packaging on Fresh Tart Cherry Fruit Quality. Proc. VIth Intl. Cherry Symposium Eds.: M. Ayala et al. Acta Hort. 1020, ISHS

Erogul, D. (2014): Effect of Preharvest Calcium Treatments on Sweet Cherry Fruit Quality. Not Bot Horti Agrobo. 42. 1:150-153.

Feliziani E.-Santini M.-Landi L.-Romanazzi G. (2013): Pre- and postharvest treatment with alternatives to synthetic fungicides to control postharvest decay of sweet cherry. Postharvest Biology and Technology. 78:133-138

Giméneza, M. J.-Valverde, J. M.-Valero, D.-Díaz-Mula, H. M.Zapata, P. J.-Serrano, M.-Moral, J.-Castillo S. (2015): Methyl salicylate treatments of sweet cherry trees improve fruit quality at harvest and during storage. Scientia Horticulturae. 197:665673

Hevia, F.-Wilckens, R.-Lanuza, P.-Mujica, C.-Olave, Y. (1998): Influence of hydrocooling and fruit colour on the behaviour of Bing sweet cherries after refrigerated storage. Acta Horticulturae. 468:731-736.

Homoki, J.-Nemes, A.-Remenyik, J. (2014): A meggy mint funkcionális élelmiszer. Agrártudományi Közlemények., 55. 4147.p o.

Inánsty, F.-Balázs, K. (2004): Meggy, cseresznye. Agroinform Kiadó, Budapest, 243. p.

Izgü, F.- Altinbay, D. (2004): Isolation and characterization of the K5-type yeast killer protein and its homology with an exo-b-1,3glucanase. Biosci. Biotechnol. Biochem. 68:685-693.

Ke, D.- Rodriguez-Sinobas, L.-Kader, A. A. (1991): Physiology and prediction of fruit tolerance to low oxygen atmospheres. J. Am. Soc. Hort. Sci. 166:253-260.
Liu, J.-Sui, Y.-Wisniewski, M.-Droby, S.- Liu, Y. (2013): Review: utilization of antagonistic yeasts to manage postharvest fungal diseases of fruit. Int. J. Food Microbiol. 167:153-160.

Lu, L.- Lu, H.-Wu, C.-Fang, W.-Yu, C.-Ye, C.-Shi, Y.-Yu, T.Zheng, X. (2013): Rhodosporidium paludigenum induces resistance and defense-related responses against Penicillium digitatum in citrus fruit. Postharvest Biol. Technol. 85:196-202.

Lurie, S. (1992): Controlled atmosphere storage to decrease physiological disorders in nectarines. Intl. J. Food Sci. Technol. 27:507-514.

Lutz, M. C.-Lopes, C. A.-Rodriguez, M. E.-Sosa, M. C.-Sangorrin, M. P. (2013): Efficacy and putative mode of action of native and commercial antagonistic yeast against postharvest pathogens of pear. Int. J. Food Microbiol. 164:166-172.

Manso, T.-Nunes, C. (2011): Metschnikowia andauensis as a new biocontrol agent of fruit postharvest diseases. Postharvest Biol. Technol. 61:64-71.

Mari, M-Martini, C.-Guidarelli, M.-Neri, F. (2012): Postharvest biocontrol of Monilinia laxa, Monilinia fructicola and Monilinia fructigena on stone fruit by two Auerobasidium pullulans strains. Biol. Control. 60:132-140.

Mihály, K.-Kovács, Cs.-Bujáki, B.-Takács, F.-Sándor, E. (2017): A sugárkezelés és a módosított légterü tárolás hatása a frissfogyasztású meggy polcállóságára In: LIX. Georgikon Napok Konferenciakiadványa (szerk.: Nagy Zita Barbara) Keszthely: Pannon Egyetem Georgikon Kar, 2017. pp. 357-368. (ISBN:978-963-9639-89-8)

Muccilli, S.-Wemhoff, S.-Restuccia, C.-Meinhardt, F. (2013): Exoglucanase-encoding genes from three Wickerhamomyces anomalus killer strains isolated from olive brine. Yeast .30:3343.

Oro, L.-Ciani, M.-Comitini, F. (2014): Antimicrobial activity of Metschnikowia pulcherrima on wine yeasts. J. Appl. Microbiol. 116:1209-1217.

Parafati, L.-Vitale, A.--Restuccia, C.-Cirvilleri, G. (2015): Biocontrol ability and action mechanism of food-isolated yeast strains against Botrytis cinerea causing postharvest bunch rot of table grape. Food Microbiol. 47:85-92.

Patterson, M. E. (1982): CA storage of cherries. p.149-154. In: D.G. Richardson and M. Meheriuk (eds.), Controlled atmosphere for storage and transport of perishable agricultural commodities. Timber Press, Beaverton, OR.

Prusky, D.-Perez, A.-Zutkhi, Y.-Ben-Arie, R. (1997): Effect of modified atmosphere for control of black spot, caused by Alternaria alternata, on stored persimmon fruits. Phytopathology 87:203-208.

Pusey, P. L.-Wilson, C. L. (1984): Postharvest biological control of stone fruit brown rot by Bacillus subtilis. Plant Disease. 68:753756.

Retamales, J.-Cooper, T.-Streif, J.-Kania, I. C. (1992): Preventing cold storage disorders in nectarines. Hort. Sci. 67:619-626.

Romanazzi, G.-Schena, L.-Nigro, F.-Ippolito, A. (1999): Preharvest chitosan treatments for the control of postharvest decay of sweet cherries and table grapes. J. Plant Pathol. 81: 237.

Shiping, T.-Qin, G.-Xu, Y. (2004): Survival of antagonistic yeasts under field conditions and their biocontrol ability against postharvest diseases of sweet cherry. Postharvest Biology and Technology. 33:327-331. 
Singh, V.-Deverall, B. J. (1984): Bacillus subtilis as a control agent against fungal pathogens of citrus fruit. Transactions in British Mycological Society. 83:487-490.

Spadaro, D.-Droby, S. (2016): Development of biocontrol products for postharvest diseases of fruit: the importance of elucidating the mechanisms of action of yeast antagonists. Trends Food Sci. Technol. 47: 39-49.

Takács, F.-Karaffa, E.-Nagy, T. (2016): Gyümölcstárolás. in: Meggy (szerk.: Nyéki J., Szabó T., Soltész M.) Újfehértó. ÉKASZ, MKSZN, NAIK. 312-318 p.

Utkhede, R. S.-Sholberg, P. L. (1986): In vitro inhibition of plant pathogens: Bacillus subtilis and Enterobacter aerogenes in vivo control of two postharvest cherry diseases. Canadian Journal of Microbiology. 32:963-967.
Wisniewski, M. E.-Wilson, C. L. (1992): Biological Control of Postharvest Diseases of Fruits and Vegetables: Recent Advances. Hortscience, VOL. 27(2).

Wisniewski, M. E-Wilson, C. L. (1992): Biological control of postharvest diseases of fruit and vegetables: recent advances. HortScience 27, 94-98.

Zhu, Y.-Yu, J.-Brecht, J.K.-Jiang, T.-Zheng, X. (2016): Pre-harvest application of oxalic acid increases quality and resistance to Penicillium expansum in kiwifruit during postharvest storage. Food Chemistry 190:537-543

Zoffoli, J. P.-Rodriguez J. (2014): Effect of Active and Passive Modified Atmosphere Packaging of Sweet Cherry. Proc. VIth Intl. Cherry Symposium Eds.: M. Ayala et al. Acta Hort. 1020, ISHS 
